\title{
Research on Design of the Logic and Process of an Operation Simulation System for Technological Innovation-based Manufacturing Enterprises
}

\author{
Shijun Tang ${ }^{1}$ and Bingxue Chen ${ }^{2}$ \\ ${ }^{1}$ City College of Wuhan University of Science and Technology, China \\ ${ }^{2}$ Wuhan University of Technology, China
}

\begin{abstract}
In this paper, based on theories of management simulation and disruptive innovation in modern enterprises, we build a business operation simulation system with technological innovation-based manufacturing enterprises at the core. We preliminarily explore and explain the design idea relating to the basic logic and process of the "operation simulation system for technological innovation-based manufacturing enterprises", which is oriented by cultivation of innovative and entrepreneurial talents.
\end{abstract}

Keywords-technological innovation, entrepreneurship; Entrepreneur Philosophy; sandbox-based teaching

\section{INTRODUCTION}

This paper build a new electronic innovation and entrepreneurship sandbox that focuses on technological innovation-based manufacturing enterprises and name it "Entrepreneur Philosophy", which is oriented by cultivation of innovative and entrepreneurial talents.

\section{BASIC LOGIC AND PROCESS OF "ENTREPRENEUR PHILOSOPHY"}

The core of "Entrepreneur Philosophy", a business operation simulation system for technological innovation-based manufacturing enterprises, is an innovative manufacturing enterprise producing and selling $\mathrm{P}$ series products. The core process of the system consists of market demand, product design and R\&D, production, and marketing $\&$ delivery.

\section{A. Market Demand}

The "Entrepreneur Philosophy"simulation of the food industry as an example: in the model design of the food industry market, consumers are biased towards the product of a distinct difference. There are three types of consumers in this industry: brand seeking type (high income crowd), quality affordable type (wage earners), economic applicable type (student population). Different consumer groups have different attention and focus on the product. This model sets consumers to choose and evaluate products according to the following five dimensions. See Table 1.

TABLE I THE FIVE DIMENSION OF PRODUCT PREFERENCES

\begin{tabular}{|c|l|}
\hline Dimension & \multicolumn{1}{c|}{ Annotation } \\
\hline Product price & $\begin{array}{l}\text { Product price refers to the price quoted by a company when it is sold. Compared with competitors, the lower the price, the } \\
\text { more consumers can obtain the approval. }\end{array}$ \\
\hline $\begin{array}{c}\text { Product } \\
\text { function }\end{array}$ & $\begin{array}{l}\text { Product function mainly refers to each company design new product selected function configuration table (BOM table), and } \\
\text { compared with competitors, the product function more in line with the consumer's functional appeal, the more can be } \\
\text { recognized by consumers. }\end{array}$ \\
\hline $\begin{array}{c}\text { Product } \\
\text { brand }\end{array}$ & $\begin{array}{l}\text { Total advertising determines how much the product brand by the company marketing department in the product investment, } \\
\text { compared with competitors, invested a total of more advertising, brand awareness is higher, more can get consumer } \\
\text { recognition. }\end{array}$ \\
\hline $\begin{array}{c}\text { Product } \\
\text { reputation }\end{array}$ & $\begin{array}{l}\text { Product reputation refers to the history of the product sales, compared with competitors, the total amount of product sales, } \\
\text { product orders, delivery, the higher the rate of completion of consumer recognition of the higher the product. }\end{array}$ \\
\hline Product sales & $\begin{array}{l}\text { Product sales refers to the total sales capacity of the company's current sales products. Compared with competitors, the } \\
\text { higher the total sales capacity, the higher the consumer recognition. }\end{array}$ \\
\hline
\end{tabular}

The three types of consumer groups designed by this the above products, as shown in Table 2. model differ in the degree of preference for the five aspects of

TABLE II PRODUCT CUSTOMER PREFERENCE RATIO

\begin{tabular}{|c|c|c|c|}
\hline & $\begin{array}{c}\text { Brand pursuit type } \\
\text { customer preference ratio }\end{array}$ & $\begin{array}{c}\text { Quality customer } \\
\text { preference ratio }\end{array}$ & $\begin{array}{c}\text { Economic applicable customer } \\
\text { preference ratio }\end{array}$ \\
\hline Product price & $15 \%$ & $30 \%$ & $50 \%$ \\
\hline Product function & $45 \%$ & $25 \%$ & $20 \%$ \\
\hline Product brand & $25 \%$ & $15 \%$ & $10 \%$ \\
\hline Product reputation & $10 \%$ & $10 \%$ & $10 \%$ \\
\hline Product sales & $5 \%$ & $20 \%$ & $10 \%$ \\
\hline
\end{tabular}

The method of product comprehensive evaluation is designed by this model: five basic scores of the product, multiplied by customer preference ratio, and then added "sum" and "sum". A comprehensive evaluation of a product, high 
share, will naturally get more market demand, conversely, less demand.

\section{B. Product Design and Product $R \& D$}

This model shows that: in general, enterprises in the fierce market competition, in order to survive and develop, must through the design and $R \& D$ to meet the needs and preferences of the sellers. At the same time, this model supports the innovative design and development of new products, and believes that the market of new products can shape new demands of the market.

1) Product design: Different consumer groups have different product function appeals, and in order to get more favor, each company needs to design new products according to these functions. In this model students can complete the design of the new product in the R \& D Department of the company. The model sets up a design fee of 30 thousand yuan for each new product design. Each company can design up to 6 products during the operation.

2) Product research and development: For the completion of the new product design, product development main duty is to carry out its research, development, testing and other work to complete the design of each product in each of the R \& D cost is 20 thousand yuan.

3) The first prize of innovative products: This model specially designs the first prize of innovative products, which is also one of the core features of this competition model. First of all, "innovative products" refers to the product design of all types of raw materials used in advanced materials and corresponding accessories products. Secondly, the so-called "first principles", refers to the company in all competitions in the first to complete the design, development and production of innovative products, and successfully market sales. Finally, the model for the first innovation of enterprises will give "the first reward", namely, the system will automatically give the price increase of $5 \%$ the first company to market, as a reward, and maintain the 2 quarter bonus time.

\section{Product Production}

In this model, the enterprise has completed the design and development of new products, it can be manufactured. The manufacturing process of the product involves the following important aspects.

1) plant purchase: This model provides "rent" and "purchase" for "plant". For the leased plant, the system will automatically deduct the corresponding rent at the beginning of each period. For the purchase of the factory, the purchase will pay the corresponding cash,

\section{2) Purchase of production line}

After the enterprise has the factory building, may purchase the production line, and is arranged in the workshop, uses for the production product. The model provides three production lines of "manual line", "automatic line" and "flexible line", which can be selected by enterprises.

3) Worker recruitment: When the enterprise layout the production line in the workshop, it is necessary to go to the talent market to recruit the corresponding production workers.

4) Raw material purchase: This model has designed four major categories of raw materials, namely: the main raw materials, secondary raw materials, packaging, accessories. This article shows the food industry market in the "Entrepreneur Philosophy" system, where the raw materials for each category contain a number of fine raw materials, as shown in Table 3.

TABLE III CLASSIFICATION OF RAW MATERIALS

\begin{tabular}{|c|c|c|c|c|c|c|}
\hline $\begin{array}{c}\text { Main } \\
\text { material } \\
\text { categories }\end{array}$ & Raw subcategory & $\begin{array}{c}\text { R \& D cycle } \\
\text { assignment }\end{array}$ & $\begin{array}{l}\text { Arrival } \\
\text { cycle }\end{array}$ & $\begin{array}{l}\text { Payment } \\
\text { cycle }\end{array}$ & Unit Price & $\begin{array}{l}\text { Emergency } \\
\text { Purchasing }\end{array}$ \\
\hline \multirow{3}{*}{$\begin{array}{r}\text { Main } \\
\text { material }\end{array}$} & plain flour & 1 & 0 & 0 & 10 & \\
\hline & graham flour & 2 & 0 & 0 & 20 & \\
\hline & Patent flour & 3 & 1 & 1 & 30 & YES \\
\hline \multirow{3}{*}{$\begin{array}{l}\text { Secondary } \\
\text { material }\end{array}$} & Plain eggs & 1 & 0 & 0 & 10 & \\
\hline & native egg & 2 & 0 & 1 & 20 & \\
\hline & Wutie egg & 3 & 1 & 1 & 50 & YES \\
\hline \multirow{3}{*}{ Packing } & Plastic & 1 & 0 & 0 & 10 & \\
\hline & Carton & 2 & 0 & 0 & 20 & \\
\hline & Wooden box & 3 & 1 & 1 & 30 & YES \\
\hline \multirow{2}{*}{ Accessories } & Fruit & 2 & 1 & 1 & 10 & YES \\
\hline & Chocolate & 2 & 1 & 1 & 20 & YES \\
\hline
\end{tabular}

This model agreed: the research and development of new products, if the raw material development cycle assignment and greater than 6 , then the product needs a quarter to complete, and the need to invest 20000 yuan in the R \& D expenses; if the raw material development cycle assignment and less than 6 , while the development cycle is 0 , investment 
R \& D funds, complete product development.

5) Enterprise product qualification certification: In the "Entrepreneur Philosophy"system, companies can obtain a variety of product qualification certification, in line with market access requirements, and improve their product competitiveness.
However, the model set different markets, consumers have what kind of certification of the enterprise will have different requirements, for consumers who can not meet the requirements of the enterprise, consumers will refuse to buy their products. Table 4 shows the requirements of the China food market qualification certification in the food industry under this model.

TABLE IV REQUIREMENTS FOR PRODUCT QUALIFICATION IN CENTRAL CHINA MARKET

\begin{tabular}{|c|c|c|c|c|c|c|c|c|c|c|}
\hline $\begin{array}{c}\text { Marketi } \\
\text { ng }\end{array}$ & Customers & $\begin{array}{c}\text { Authentication } \\
\text { category }\end{array}$ & $\begin{array}{c}1 \\
\text { quarter }\end{array}$ & $\begin{array}{c}2 \\
\text { quarter }\end{array}$ & $\begin{array}{c}3 \\
\text { quarter }\end{array}$ & $\begin{array}{c}4 \\
\text { quarter }\end{array}$ & $\begin{array}{c}5 \\
\text { quarter }\end{array}$ & $\begin{array}{c}6 \\
\text { quarter }\end{array}$ & $\begin{array}{c}7 \\
\text { quarter }\end{array}$ & $\begin{array}{c}8 \\
\text { Quarter }\end{array}$ \\
\hline \multirow{6}{*}{$\begin{array}{c}\text { Central } \\
\text { China }\end{array}$} & \multirow{2}{*}{$\begin{array}{c}\text { The pursuit of } \\
\text { brand-type } \\
\text { crowd }\end{array}$} & ISO9001 & & & & $\sqrt{ }$ & $\sqrt{ }$ & $\sqrt{ }$ & $\sqrt{ }$ & $\sqrt{ }$ \\
\hline & & $\begin{array}{l}\text { QS Food } \\
\text { certification }\end{array}$ & & & & & & & $\sqrt{ }$ & $\sqrt{ }$ \\
\hline & \multirow{2}{*}{$\begin{array}{l}\text { Quality } \\
\text { affordable } \\
\text { crowd }\end{array}$} & ISO9001 & & & & & & $\sqrt{ }$ & $\sqrt{ }$ & $\sqrt{ }$ \\
\hline & & $\begin{array}{c}\text { QS Food } \\
\text { certification }\end{array}$ & & & & & & & & $\sqrt{ }$ \\
\hline & \multirow{2}{*}{$\begin{array}{c}\text { Economically } \\
\text { applicable } \\
\text { population }\end{array}$} & ISO9001 & & & & & $\sqrt{ }$ & $\sqrt{ }$ & $\sqrt{ }$ & $\sqrt{ }$ \\
\hline & & $\begin{array}{l}\text { QS Food } \\
\text { certification }\end{array}$ & & & & & & & & $\sqrt{ }$ \\
\hline
\end{tabular}

\section{Marketing Sales}

When the enterprise completes the product manufacture work, must begin to consider the product the market question, namely the marketing question. In this model, marketing includes market development, product advertisement, sales staff recruitment and training, order quotation and so on.

1) market development: This model is compared with previous business simulation game in the market, this design links "the Internet channel" into the system, therefore, the model of the whole market is divided into six regional markets, including: Central, north, Southern China, East China, northwest, internet. In addition to developing a certain period of time, each enterprise needs a development fee. Each company can sell its products to consumers through sales channels that have been developed in different market areas.

2) product advertising: This model makes the following set for the "product advertising": each product can invest a sum of advertising costs; a period of investment in advertising is a cumulative effect for the next several quarters, when the season into effect, with the passage of time, the distance from the current quarter is more long, the effect is gradually reduced.

3) Sales staff: The model establishes that the company can recruit sales personnel in the talent market of the trading market.

4) Market demand: Model design: in each business quarter, the enterprise will find several market orders from different consumer groups in the market where it has been developed. Moreover, in each quarter of the year, each market segment contains a diverse range of market requirements for multiple consumer groups. This paper takes the market demand quantity of a set of central China market in the food industry competition model of "Entrepreneur Philosophy" as an example, and the market demand data are shown in Table 5.

\section{TABLE V STRUCTURE OF DEMAND IN CENTRAL CHINA MARKET (GROUP ONE)}

\begin{tabular}{|c|c|c|c|c|c|c|c|c|c|c|c|c|c|c|c|c|c|}
\hline \multicolumn{18}{|c|}{ Market demand statement (unit: Unit) } \\
\hline \multicolumn{2}{|c|}{$\begin{array}{l}\text { Number of } \\
\text { groups: } 1\end{array}$} & $\begin{array}{c}1 \\
\text { quarter }\end{array}$ & \begin{tabular}{|c|} 
Collect \\
ion \\
cycle
\end{tabular} & $\begin{array}{c}2 \\
\text { quarter }\end{array}$ & $\begin{array}{c}\text { Collecti } \\
\text { on } \\
\text { cycle }\end{array}$ & $\begin{array}{c}3 \\
\text { quarter }\end{array}$ & \begin{tabular}{|c|} 
Collec \\
tion \\
cycle \\
\end{tabular} & $\begin{array}{c}4 \\
4 \\
\text { quarter }\end{array}$ & \begin{tabular}{|c|} 
Collec \\
tion \\
cycle \\
\end{tabular} & \begin{tabular}{|c|}
5 \\
quarter
\end{tabular} & \begin{tabular}{|c|} 
Collec \\
tion \\
cycle
\end{tabular} & $\begin{array}{c}6 \\
\text { quarter }\end{array}$ & $\begin{array}{c}\text { Collecti } \\
\text { on } \\
\text { cycle }\end{array}$ & \begin{tabular}{|c|}
7 \\
quarter
\end{tabular} & \begin{tabular}{|c|} 
Collec \\
tion \\
cycle \\
\end{tabular} & \begin{tabular}{|c|}
8 \\
quarte \\
$\mathrm{r}$ \\
\end{tabular} & $\begin{array}{l}\text { Collect } \\
\text { ion } \\
\text { cycle }\end{array}$ \\
\hline \multirow{3}{*}{$\begin{array}{l}\text { Central } \\
\text { China }\end{array}$} & \begin{tabular}{|c|}
$\begin{array}{c}\text { Econo } \\
\text { mical } \\
\text { type }\end{array}$ \\
\end{tabular} & 406 & 0 & 438 & 0 & 471 & 0 & 505 & 0 & 531 & 0 & 506 & 0 & 484 & 0 & 471 & 0 \\
\hline & \begin{tabular}{|l|} 
Qualit \\
y type
\end{tabular} & 318 & 0 & 318 & 0 & 372 & 0 & 406 & 0 & 415 & 0 & 427 & 0 & 431 & 0 & 440 & 0 \\
\hline & \begin{tabular}{|l|}
$\begin{array}{l}\text { Brand } \\
\text { pursuit }\end{array}$ \\
\end{tabular} & 226 & 0 & 226 & 0 & 271 & 1 & 306 & 1 & 316 & 1 & 338 & 1 & 360 & 1 & 372 & 1 \\
\hline
\end{tabular}

The demand is the number of a set of conditions, in the actual teaching or in the game, the number of real market demand for products will be enlarged.

The quantity demanded of a particular type of product in a market $=$ a market of certain types of products in 1 groups under the conditions of the base $\times$ team number.

5) Order delivery: The model design: if the product supply, enterprises can use high grade products to market demand 
delivery orders.

\section{CONCLUSION}

This paper explores the establishment of an "operation simulation system for technological innovation-based manufacturing enterprises", which is oriented by cultivation of innovative and entrepreneurial talents in qualities and capabilities, focuses on innovation-based manufacturing enterprises. We expound the basic logic and process of "market demand - product design and R\&D - production marketing and delivery".

\section{REFERENCES}

[1] Shijun Tang. Discussion on the development and innovation of the "Second Class" of ERP talents training [J].Contemporary Economic, 2013(7).

[2] LinYan , Shijun Tang.SCM Simulation Course [M].China Railway Publishing House, 2014.9. 